\title{
Ecological roles for water-borne metabolites from Antarctic soft corals
}

\author{
Marc Slattery ${ }^{1,2, *}$, Mark T. Hamann ${ }^{1}$, James B. McClintock ${ }^{2}$, Tony L. Perry ${ }^{1}$, \\ Melany P. Puglisi ${ }^{1}$, Wesley Y. Yoshida ${ }^{3}$
}

${ }^{1}$ University of Mississippi, Department of Pharmacognosy and National Center for the Development of Natural Products, Research Institute of Pharmaceutical Sciences, School of Pharmacy, University, Mississippi 38677, USA

${ }^{2}$ University of Alabama at Birmingham, Department of Biology, Birmingham, Alabama 35294, USA

${ }^{3}$ University of Hawaii, Department of Chemistry, Honolulu, Hawaii 96822, USA

\begin{abstract}
Prior studies have documented predator deterrence and antifouling activities for organic extracts of the Antarctic soft corals Alcyonium paessleri and Gersemia antarctica under surficial contact situations. Field observations and subsequent seawater callections support the release of waterborne allelochemicals by these 2 species. A paesslen and $G$. antarctica released organics totaling 1.54 and $1.26 \mathrm{mg} \mathrm{l}^{-1}$ of seawater extracted, respectively. The compounds from A. paessleri were comprised of $86 \%$ sterols by mass and they diluted to non-detectable levels within 1 to $2 \mathrm{~cm}$ of the colony surface. The absolute production rates for the sterols varied positively with colony size and ranged from 3.4 to $6.6 \mathrm{mg} \mathrm{l}^{-1}$ seawater extracted $\mathrm{d}^{-1}$. Three of the 4 sterols isolated from $A$. paessleri deterred seastar predators; included amongst these compounds was the primary metabolite, cholesterol. In contrast, $G$. antarctica released many classes of compounds and few in any major quantities. Nonetheless, the organic fraction of seawater collected near this soft coral showed potent antibacterial activity against 3 sympatric microbes. Bioautography was used to guide isolation of the antimicrobial fraction which contained homarine, trigonelline, and a minor metabolite. Homarine was responsible for most of the bioactivity noted during the bioautography assay.
\end{abstract}

KEY WORDS: Allelochemicals Soft corals Predator deterrence Antimicrobials Antarctica

\section{INTRODUCTION}

Allelopathic interactions, specifically those chemical interactions which act in an inhibitory fashion, are common amongst higher plants and have significant implications for the structure of plant communities (Whitaker \& Feeny 1971, Rice 1984, Inderjit et al 1995). The transfer of an allelochemical between spatially disjunct terrestrial species can occur via volatiles, exudates, and aqueous leachates through either air or soil. In contrast, hydrodynamic conditions in marine habitats would appear to favor contact-mediated chemical interactions. Although chemical defenses have been well documented in marine algae and invertebrates, most commonly as predator deterrent

·E-mail:mslatter@olemiss.edu
Compounds and to prevent surficial fouling (Paul 1992, Pawlik 1993, Hay 1996), few studies have identified actual water-borne chemical compounds (Coll et al. 1982. Walker et al. 1985). Nonetheless, several investigators have hypothesized the existence of water-borne inhibitory allelochemicals from various marine organisms (Jackson \& Buss 1975. Sammarco et al. 1983, Bak \& Borsboom 1984, Wahl 1989, Davis et al. 1991, Maida et al. 1995), although experimental evidence for their ecological roles is rare (Webb \& Coll 1983, Porter \& Targett 1988, Schmitt et al. 1995).

The Antarctic soft corals Alcyonium paessleri and Gersemia antarctica are conspicuous members of hardand soft-bottom communities, respectively, throughout McMurdo Sound, Antarctica (Slattery \& McClintock 1995, 1997). The selective pressures in this old and extreme biome are consistent with those required for the evolution of chemical defenses and examples from 
diverse phyla have been documented (Dayton et al. 1974, Pearse et al. 1991, McClintock 1994a). Previous studies provided evidence for bioactive compounds from both of these soft corals which deter predators and prevent microbial fouling (Slattery \& McClintock 1995, Slattery et al. 1995); however, potential extraction inconsistencies prevented the identification of the responsible metabolites. In the field, A. paessleri and $G$. antarctica are subject to relatively rare predation events by specialists, including the pycnogonids Collosendeis spp. and Thavmastopycnon spp. and the opisthobranch Notoaeolidia sp., and they are avoided by the more common generalist predatory seastars and fish (Slattery \& McClintock 1997). A. paessleri is consistently avoided by nonvisual predators such as the seastar Perknaster fuscus without contact between the 2 species (Slattery pers. obs.; Fig. 1). This suggests these potential predators are responding to waterborne allelochemical(s) released by the soft coral. The purpose of this study was to verify the presence of water-borne metabolites from the Antarctic soft corals A. paessleri and $G$. antarctica, to determine the structuire of these cumpounds, and to assess the ecological roles of these allelochemicals.

\section{MATERIALS AND METHODS}

Allelochemical isolation. Water samples were collected in situ adjacent to the soft corals Alcyonium paessleri and Gersemia antarctica at Arrival Heights (77 $\left.51^{\prime} \mathrm{S}, 166^{\circ} 39^{\prime} \mathrm{E}\right)$ and Explorer's Cove $\left(77^{\circ} 34^{\prime} \mathrm{S}\right.$, $\left.163^{\circ} 35^{\prime} \mathrm{E}\right)$, McMurdo Sound, Antarctica, respectively, between September and February 1993-1994 (see Slattery \& McClintock 1995 for a description of the sites]. Each water sample was collected in four $60 \mathrm{cc}$ disposable syringes aligned with their tips $6 \mathrm{~cm}$ apart in a plexiglass array. The syringe plungers were connected by a plexiglass crossbar which allowed a single $240 \mathrm{ml}$ aliquot of seawater to be simultaneously sampled near the soft coral of interest. Eight syringe arrays were constructed and carried on each dive such that replicate and/or multiple (for pooling) samples could be obtained. Initially we were interested only in the presence or absence of water-borne metabolites near A. paessleri or $G$. antarctica. Four syringe arrays were used to sample seawater $1 \mathrm{~cm}$ from the surface of 4 separate soft corals; the other 4 syringe arrays were used to collect control seawater samples $0.25 \mathrm{~m}$ above the benthos and $\geq 1 \mathrm{~m}$ away from any marine invertebrate. The samples were subsequently pooled in the laboratory to yield $960 \mathrm{ml}$ of seawater collected near $A$. paessleri, $960 \mathrm{ml}$ of seawater collected near $G$. antarctica, and $960 \mathrm{ml}$ of control seawater from each of the 2 study sites. These samples were mixed with an equal

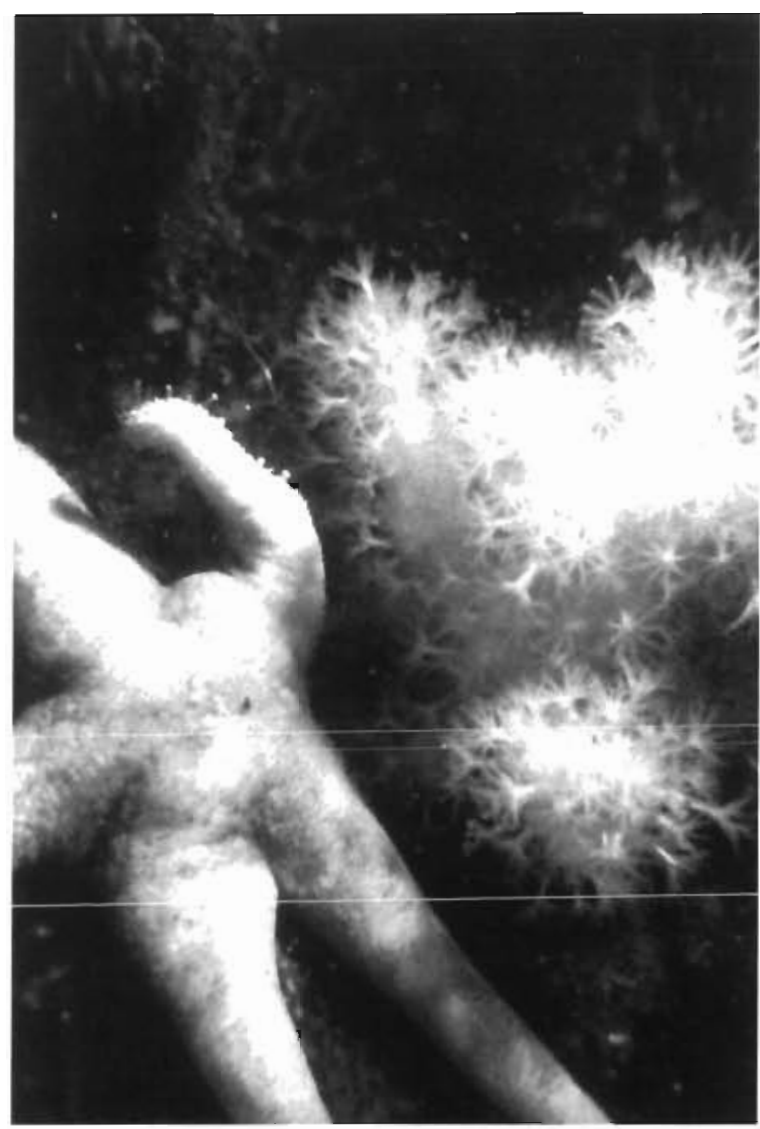

Fig. 1 Perknaster fuscus avoiding Alcyonium paessleri. The Antarctic seastar avoids contact with the soft coral in $\mathrm{MC}$ Murdo Sound via a $90^{\circ}$ turn. In 3 field seasons, and hundreds of man-hours diving, we recorded 56 and 17 'close-encounters' between $A$. paessleri and the seastars Odontaster valldus and $P$. fuscus, respectively (i.e. a soft coral in the direct path of a motile seastar eliciting a clear change of seastar direction to avoid contact). Note the withdrawal of the seastar arm pror to contact (if contact had occurred, the soft coral polyps would be retracted); the chemosensory tubefeet of the seastar are also visible at the terminal region of the ray

volume of dichloromethane (DCM) in 2 l separatory funnels and were allowed to partition across the aqueous-organic boundary layer. This procedure was repeated 3 successive times, which effectively removed all organic compounds (verified by reverse phase thinlayer chromatography (TLC) developed in a solvent system of 6:4 acetonitrile-DCM]. Although the compounds are water soluble, they include lipophilic properties which allow them to be extracted from seawater using a relatively non-polar solvent such as DCM. Comparisons between the TLCs of DCM extracts of control seawater, DCM extracts of seawater collected near soft corals (hereafter the water-borne organic fractions), and DCM extracts of whole soft corals indicated that $A$. paessleri-and $G$. antarctica-specific metabolites were leaching into the surrounding sea- 
water. In order to assess how common water-borne metabolites were in the nearshore benthic community and to further verify a soft coral origin for the waterborne metabolites we also sampled, as above, near 7 of the most common sessile invertebrates (sponges: Dendrilla membranosa, Homaxinella balfourensis, Kirkpatrickia variolosa, Latrunculia apicalis, and Mycale acerata; anemone: Urticinopsis antarcticus; and tunicate: Cnemidocarpa verrucosa). The DCM extracts of the water samples and whole animal tissues were TLCed, as above; however none of the benthic invertebrates released metabolites into the surrounding seawater at concentrations high enough to be visualized by TLC, if at all.

The DCM extracts of seawater collected near Alcyonium paesslerii and Gersemia antarctica were redissolved in a 6:4 acetonitrile-DCM solvent mixture for injection into a high performance liquid chromatography system (HPLC; Beckman LC2 Gold System configured to Refractive Index and UV/Visible light detectors) and separation across a reverse phase column. The column and guard were $250 \times 10 \mathrm{~mm}$ and $50 \times 10 \mathrm{~mm}$, respectively (Phenomenx Ultracarb ODS $30,5 \mu \mathrm{m}$ ), and were eluted with a $6: 4$ acetonitrile-

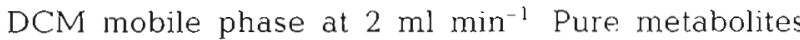
were identified using ${ }^{1} \mathrm{H}$ - and ${ }^{13} \mathrm{C}$-Nuclear Magnetic Resonance (NMR) spectroscopy experiments (Bruker 300 and $400 \mathrm{MHz}$, University of Mississippi; and GE GN Omega $500 \mathrm{MHz}$, University of Hawaii) and by magnetic sector High Resolution Mass Spectroscopy (VG-70SE). In order to maximize the amount of metabolites available for subsequent bioassays (see below). we extracted multiple soft corals $(\geq 2 \mathrm{~kg}$ wet tissue mass each of $A$. paessleri and $G$. antarctica). Tissue samples were successively wet extracted for $24 \mathrm{~h}$ each in hexanes, chloroform, methanol, and 7:3 methanolwater The crude extracts were further fractionated using size exclusion (LH20), silica flash chromatography, and finally RPC18-HPLC. Reverse phase TLC (solvent systems of $4: 1$ hexanes-ethyl acetate, $6: 4$ acetonitrile-DCM, and 1:9 $\mathrm{H}_{2} \mathrm{O}$-methanol) was used to guide the fractionation steps via comparisons to the comigrating water-borne metabolite standards; the specific metabolites isolated from the soft coral tissues were also identified by nuclear magnetic resonance to verify that these were present in the water-borne organic fractions. The pure metabolites of $A$. paessleri and $G$. antarctica were subsequently traced back to the methanol extract fraction in our original wet tissue extracts.

Quantification of allelochemicals. The pure metabolites released from Alcyonium paessleri were used to generate a standard curve to quantify the concentration of the metabolites, via analytical HPLC (Lindquist et al. 1992, Slattery et al. in press), in the sampled seawater and in extracts of colonies ( $\mathrm{n}=3$ ) from 4 sites surrounding McMurdo Sound (Cape Evans: $77^{\circ} 40^{\circ} \mathrm{S}$, $166^{\circ} 25^{\prime} \mathrm{E}_{i}$ Arrival Heights: $77^{\circ} 50^{\prime} \mathrm{S}, 166^{\circ} 40^{\prime} \mathrm{E}_{i}$ Explorer's Cove: $77^{\circ} 35^{\prime} \mathrm{S}, 163^{\circ} 55^{\prime} \mathrm{E}$ : and Granite Harbor: $77^{\circ} 00^{\prime} \mathrm{S}, 162^{\circ} 40^{\prime} \mathrm{E}$ ). The pure metabolites of Gersemia antarctica were unavailable to quantify water samples via analytical techniques; thus, the water sample concentrations represent the actual mass of each organic fraction recovered from seawater as weighed on a Mettler analytical balance. The data generated raised additional questions regarding the dilution of the metabolites into the surrounding seawater and the daily rate of metabolite production. To address the former question we sampled soft corals in the field, as above, with the following difference. The syringe array was oriented perpendicular to a soft coral such that the syringe tips were then $1,7,13$, and $19 \mathrm{~cm}$ from the surface of the soft corals. Thus, each syringe in an array represented an individual $60 \mathrm{ml}$ 'distance' sample and multiple arrays positioned around a particular soft coral were used to pool enough seawater for analysis (= $240 \mathrm{ml}$ ). Our first set of samples indicated the metabolites diluted to extinction between 1 and $7 \mathrm{~cm}$; we therefore modified the array to include $20 \mathrm{~cm}$ lengths of teflon tubing ( $1 \mathrm{~mm}$ inner diameter, i.d.) connected to the syringe tips by luer-locks. The ends of the teflon tubes were taped to a plastic ruler at $0.5,1$, 1.5 , and $2 \mathrm{~cm}$ from the edge which was set perpendicular to the soft coral surface. This effectively narrowed the sampling distance from the soft coral surface to a region that was relevant given the dilution observed Dye studies in a 213 l flow-through aquaria confirmed that each sample represented a distinct replicate which did not cross-contaminate the neighbor samples. Five replicate A. paessleri colonies were sampled using multiple syringe arrays to assess metabolite dilution over distance. Each of the pooled distance samples from replicate soft corals were separated in a 11 separatory funnel, as above, and the resulting organic material was quantified by analytical HPLC.

The absolute rate of metabolite production, for Alcyonium paessleri only, was assessed under laboratory conditions. We collected 9 soft corals from approximately $25 \mathrm{~m}$ depth at Arrival Heights; these represented 3 distinct size classes (and potentially recruitment events) of 3 soft corals each. The soft corals were maintained for at least $96 \mathrm{~h}$ in flow-through tanks under ambient conditions (temperature $\sim-1.8^{\circ} \mathrm{C}$, photoperiod $=24$ h daylight, flow $=11 \mathrm{~min}^{-1}$; Barry \& Dayton 1988, Pearse et al. 1991). Prior to use, each soft coral was placed within a $38 \mathrm{l}$ flow-through aquaria for $6 \mathrm{~h}$ to recover from handling. All 9 colonies extended polyps to resume feeding (an indication of colony health; Slattery \& Bockus 1997), providing evidence that our laboratory conditions were not stressful to the 
test subjects. A plexiglass sample chamber fashioned as described by Coll et al. (1982), but smaller $(10 \times 10 \times$ $20 \mathrm{~cm} ; 21$ volume), was placed over the soft coral within the flow-through aquaria. The chamber was connected by 4 seperate teflon tubing lines $(1.2 \mathrm{~cm}$ i.d.) to an ISCO ${ }^{\mathrm{TM}}$ sampler, which removed approximately all of the chamber seawater volume every $6 \mathrm{~h}$ (= quarterly sample). The chamber refilled with ambient seawater from the surrounding flow-through aquaria via small holes drilled in the plexiglass chamber walls (i.e. as seawater was pumped out, it was replaced from the surrounding aquaria). Each quarterly seawater sample was pumped into 2 independent 1 l nalgene bottles within the ISCO carousel. Over a $24 \mathrm{~h}$ period, 8 nalgene bottles representing 4 quarterly seawater collections were obtained. Each quarterly seawater sample was partitioned in a 2 l separatory funnel, as above, dried under vacuum, and the resulting water-borne organic fraction was quantified by analytical HPLC as $\mathrm{mg}$ of compound per liter of seawater extracted (mg $\mathrm{I}^{-1}$ ). There were no temporal trends with respect to the 4 quarterly seawater samples for each size class of soft coral $(\mathrm{n}=3$ replicates; ANOVA: $\mathrm{p} \geq 0.05)$. Thus, all analytical HPLC data for each size class of soft coral were pooled ( $\mathrm{n}=12$ replicates) as an absolute metabolite production rate $\left(\mathrm{mg} \mathrm{l}^{-1} \mathrm{~d}^{-1}\right)$.

Allelochemical bioassays. Semi-pure and pure Alcyonium paessleri and Gersemia antarctica metabolites were tested in 2 sets of bioassays, one designed to assess the responses of marine invertebrates and the other to assess the responses of marine bacteria to the water-borne metabolites. A tube-foot bioassay was utilized to guide the purification of the water-borne compounds from $A$. paessleri; the water-borne metabolites of $G$. antarctica did not appear to influence predatory seastars in laboratory assays and predatory seastars rarely co-occur with this soft coral in the field (Slattery unpubl. data). The tube feet of many seastars serve as chemosensory organs (Sloan 1980); thus, the tube foot bioassay provided a mechanism to assess the role of metabolites in deterrence of a potential predator (McClintock et al. 1994a, Slattery \& McClintock 1995). Since the metabolites of interest interact with the seastars without surficial contact, we modified the published protocol by redissolving the water-borne organic fractions in ethanol and then releasing the suspension from an eppendorf pipettor across the tube feet (see Bryan et al. 1997 for a modification of this technique). The bioassay was conducted using the common omnivorous seastar Odontaster validus held in $1 \mathrm{l}$ glass bowls of filtered seawater (FSW) at an ambient temperature $\left(-1.8^{\circ} \mathrm{C}\right)$. The water-borne organic fraction and subsequent purified metabolites were resuspended in ethanol at an equivalent volume to that of the removed seawater. A $10 \mu \mathrm{l}$ aliquot of the sus- punsion was released from a distance of $1 \mathrm{~cm}$ under the extended terminal tube feet of the seastars. The ethanol-fraction suspension was visibje as a density gradient which rose as a plume into the tube feet eliciting a retraction response, often followed by a flight behavior on the part of the seastar. The tube-feet retraction period, measured up to $60 \mathrm{~s}$, was recorded for 15 replicate experimental and controls trials. An individual seastar was subjected to a single experimental condition (i.e. 1 of the soft coral metabolites resuspended in ethanol) and each control condition in a randomized order; no seastar was used more than once in the bioassays. The control conditions included a carrier solvent control (ethanol only), a mechanical contro] for the water motion (seawater only), a negative control for seastar behavior $\left(0.1 \mathrm{M} \mathrm{CuSO}_{4}\right.$ in ethanol), and a positive control for seastar behavior (pureed fish muscle in ethanol; see below).

One pure metabolite from Alcyonium paessleri leachate seawater was isolated and subsequently identified while we were still in Antarctica. The compound, cholesterol, was available from commercial sources (Sigma Corp.); thus, we were able to assay this pure metabolite against a suite of motile benthic invertebrates (see Table 2 for species list) in a plexiglass 'Y-maze'. Y-maze studies have been used previously to assess chemosensory preferences in marine invertebrates (Tyndale et al. 1994, Slattery et al. in press). Our $y$-maze was based on the design outlined in Castilla \& Crisp (1970) but it included upstream collimators consisting of 3 plexiglass panels with drill holes $(2 \mathrm{~mm}$ diameter) spaced evenly $(1 \mathrm{~mm})$ apart. The panels were placed perpendicular to water flow at 10,20, and $27.6 \mathrm{~cm}$ from water incurrent portals and dye studies confirmed that this provided a uniform and uni-directional flow pattern. Briefly, the plexiglass y-maze consisted of 2 arms, with incurrent seawater portals adjusted for equal flow rates $\left(1.0 \mathrm{ml} \mathrm{min}^{-1}\right)$, that measured $30.5 \mathrm{~cm}$ long $\times 15.2 \mathrm{~cm}$ wide and $15.2 \mathrm{~cm}$ deep; the leg of the $y$-maze was $45.7 \mathrm{~cm}$ long. The arms narrowed to $10.2 \mathrm{~cm}$ in the choice area (i.e. the point at which the $y$-maze arms meet the leg) and widened back to $15.2 \mathrm{~cm}$ at the base of the $y$-maze as recommended by Castilla \& Crisp (1970). The entire y-maze was immersed $10.2 \mathrm{~cm}$ into a $122 \mathrm{~cm}$ diameter flowthrough holding tank; this coincided with the maximal seawater depth within the $y$-maze. The $y$-maze was leveled in this position on 3 stacks of cinder blocks such that the volume of the surrounding holding tank assured a stable ambient temperature $\left(-1.8^{\circ} \mathrm{C}\right)$ within the $y$-maze. The flow rate of $10 \mathrm{ml} \mathrm{min}{ }^{-1}$ represented a compromise between recorded environmental flow rates (Barry \& Dayton 1988) and minimal mixing to prevent precipitation of our metabolite out of solution. To facilitate invertebrate movement up into the arms of 
the $y$-maze, pureed fish muscle (Dissostichus mawsonii: $5 \mathrm{~g}$ in $20 \mathrm{ml}$ FSW) was added to cloth bait bags and placed between the first set of collimator panels and the incurrent seawater portals. This provided a slow leaching of facilitory chemical signals into the $y$-maze which induced movement of the test organisms up to the choice area. Multiple trials utilizing each invertebrate ( $n=30$ per species) and only the bait bags as chemical cues at various times throughout the experiment indicated no preference for either arm of the $y$-maze $\left(\chi^{2} \geq 0.05\right)$ and thus no significant differences in leaching rates of the bait bags. While it is unclear what concentration of metabolites were leached from the bait bags, it is likely that cholesterol was released at significantly lower levels than from the soft corals (i.e. in the field, fish carcasses were never avoided by the same marine invertebrates we utilized in the $y$-maze assays; Slattery pers. obs.). We were interested in testing the pure metabolite at concentrations relevent to observed in situ levels so we produced a concentrated stock solution of the pure metabolite in ethanol (4.16 $\mathrm{mg} \mathrm{m}^{-1}$ ) and introduced a $2 \mathrm{ml}$ aliquot of the sample every minute via burette into the flow of one arm at a point $2.5 \mathrm{~cm}$ upstream from the final collimator panel. Assuming an idealized situation of equal dilution of the aliquot throughout the remaining length/volume of that arm of the $y$-maze (distance $=7.6 \mathrm{~cm}$, volume $\sim 1000 \mathrm{ml}$ ), we were able to mathematically determine that this stock solution would dilute to ecological levels of the metabolite $\left(0.5 \mathrm{mg} \mathrm{l}^{-1}\right)$ by the time it reached the choice area (Fischer et al 1979, McGhee 1991). Dye studies conducted subsequent to the experimental trials indicated approximately $75 \%$ dilution of the sample into the remaining volume at the choice area; thus, our results may represent a slight overestimate of the effects of this compound under field conditions. However, even at a maximal concentration of approximately $0.63 \mathrm{mg} \mathrm{l}^{-1}$ (i.e. $25 \%$ greater than expected concentration), these assays were still conducted within the seawater metabolite dilution range (see Fig. 3). The pure metabolite aliquot $(=2 \mathrm{ml}$ ) was delivered in a random assignment to either arm of the $y$-maze while an equal volume of the control aliquot (ethanol only) was delivered to the alternate arm. The $y$-maze was thoroughly cleaned and flushed between each trial; 10 to 20 replicates were conducted for each species and all animals were used only once in the assay. When a test organism returned to the leg of the $y$-maze rather than proceeding up one of the arms, that replicate was dropped from trials and repeated using a naive animal.

The water-borne organic fractions of Alcyonium paessleri and Gersemia antarctica were also examined for antimicrobial activity against 3 sympatric species of bacteria (Alteromonas sp., Moraxella sp, and Psychro- bacter sp.; Slattery et al. 1995). In order to assess inhibition of bacterial growth in suspension (as opposed to surficial growth; Slattery et al. 1995), the 3 bacterial isolates were cultured on dilute marine agar plates, transferred into sterile seawater and marine broth (15:1) (= SSWB) and incubated for $48 \mathrm{~h}$ at $0^{\circ} \mathrm{C}$, and transferred again into $15 \mathrm{ml} \mathrm{SSW}$ within sterile $20 \mathrm{ml}$ scintillation vials. The initial density of each bacterial suspension was adjusted to $7,5 \times 10^{6}$ cells $\mathrm{ml}^{-1}$ by dilution with SSW. Cell density was determined directly within the vials using a turbidity meter calibrated to a standard curve generated by direct counts of DAPI (4,6-diamidino-2-phenylindole) stained bacteria on an epifluorescence microscope. The water-borne organic extracts for $A$. paessleri and $G$. antarctica were tested at 1.54 and $1.26 \mathrm{mg} \mathrm{l}^{-1}$, respectively (i.e. water column concentrations; see Fig. 2). Stock solutions of the water-borne organic extracts from both soft corals were produced by dissolving the extracts in a minimal volume of ethanol and diluting to an appropriate volume using SSWB. Thus, 4.62 or $3.78 \mathrm{mg}$ of $A$ paess leri and $G$. antarctica seawater extracts, respectively, were dissolved in $100 \mathrm{ml}$ of ethanol to produce 30 -fold concentrated stock solutions which were diluted back to the aforementioned water-borne concentrations in the SSWB. Aliquots of the stock solutions $(=500 \mu \mathrm{l})$ or a solvent control (= $500 \mu$ l ethanol only) or an antibiotic control (10 $\mathrm{\mu g} \mathrm{ml}^{-1}$ streptomycin) were innoculated into the scintillation vial bacterial growth chambers ( $\mathrm{n}=5$ replicates for each treatment). The bacteria were incubated for $72 \mathrm{~h}$ at $0^{\circ} \mathrm{C}$ on a shaker table in a laboratory growth chamber with daily turbidity measurements to assess changes in growth rate. The water-borne organic extract of $A$. paessleri had little effect on bacterial growth (percent reduction in bacterial cell numbers after $72 \mathrm{~h}$ compared to controls: $7 \pm 3$, $9 \pm 3$, and $4 \pm 1$ in the presence of Alteromonas sp. Moraxella sp., and Psychrobacter sp., respectively); thus, only the results from $G$. antarctica are reported below

To determine the specific metabolites responsible for the antibacterial activity of the water-borne organic extracts from Gersemia antarctica, a variation of the bioautography assay was conducted. Briefly, dilute marine agar plates were prepared and these were innoculated with a 'lawn' of 1 of the 3 bacterial species ( $\mathrm{n}=3$ plates per bacterial species). The water-borne extract from $1 \mathrm{l}$ of seawater (= $1.26 \mathrm{mg}_{\text {; }}$ see Fig. 2) was concentrated in ethyl acetate and spotted onto 6 normal phase TLC plates $(9.5 \mathrm{~cm}$ long), via a capillary tube, $5 \mathrm{~mm}$ from a side edge and these were developed in a 4:1 hexanes-ethyl acetate mobile phase, effectively separating all metabolites (visualized by UV at $\lambda=254 \mathrm{~nm}$ ). Three control TLCs ( $\mathrm{n}=1$ plate per bacterial species) were treated identically but no sample 
was spotted on the origin. The TLC plates were embedded edgewise into the marine agar plates (duplicate TLCs tested for each bacterial. species) such that the separated metabolites made contact with the edge of the agar and, consequently, the bacterial lawn. The bacterial plates were incubated for $96 \mathrm{~h}$ at $0^{\circ} \mathrm{C}$ and then an average zone of inhibition radiating out from each metabolite contact point was determined from the duplicate plates. The average Rfs (retention factor = distance compound moves/distance solvent moves) of all metabolites were also recorded and, specifically for those that induced a zone of inhibition, these data provided the conditions for further HPLC purification. Following purification and structure elucidation of specific water-borne metabolites from $G$. antarctica at the University of Mississippi, the metabolites were resolubilized and TLCed under identical conditions to those used in Antarctica. This process provided enough chemical resolution to identify the specific bioactive metabolite. Pure standards of the 2 major metabolites were further tested against archived cultures of the Antarctic microbes using the bioautography techniques described above. The concentration of the pure homarine:trigonelline mixture in the $G$. antarctica extract (see Fig. 2) was approximately $0.32 \mathrm{mg} \mathrm{l}^{-1}$ (based on NMR proton signal integration); thus, we tested each metabolite at $0.16 \mathrm{mg} \mathrm{l}^{-1}$ in the bioautography assay conducted at the University of Mississippi.

All statistical analyses were conducted using StatView 4.5 for Macintosh (Abacus Concepts, Berkeley, CA)

\section{RESULTS}

\section{Quantification of allelochemicals}

The soft corals Alcyonium paessleri and Gersemia antarctica released water-borne compounds into the surrounding seawater (1.54 and $1.26 \mathrm{mg} \mathrm{l}^{-1}$ seawater within $1 \mathrm{~cm}$ of the soft coral surfaces; Fig. 2). A. paessleri released primarily sterols including cholesterol (31\%), 22-dehydrocholesterol ( 19\%), 24-methylenecholesterol $(-25 \%)$, and 22 -dehydro-7 $\beta$-hydroxycholesterol $(1.1 \%)$, as well as some other minor unidentified metabolites. Of these 4 metabolites only 22 dehydro-7 $\beta$-hydroxycholesterol exhibited site-specific variability in tissue concentrations. Levels were significantly higher at New Harbor $(0.47 \pm 0.10 \%$ dry mass) ( $\mathrm{p} \leq 0.0367$; ANOVA: $F=4.641$, Scheffe's: $p \leq 0.0532)$ compared to Cape Evans (0.26 \pm 0.05$)$ the levels were not significant compared to Arrival Heights and Granite Harbor $(0.29 \pm 0.07$ and $0.33 \pm$ 0.07 , respectively). G. antarctica released the compounds homarine and trigonelline in approximately a

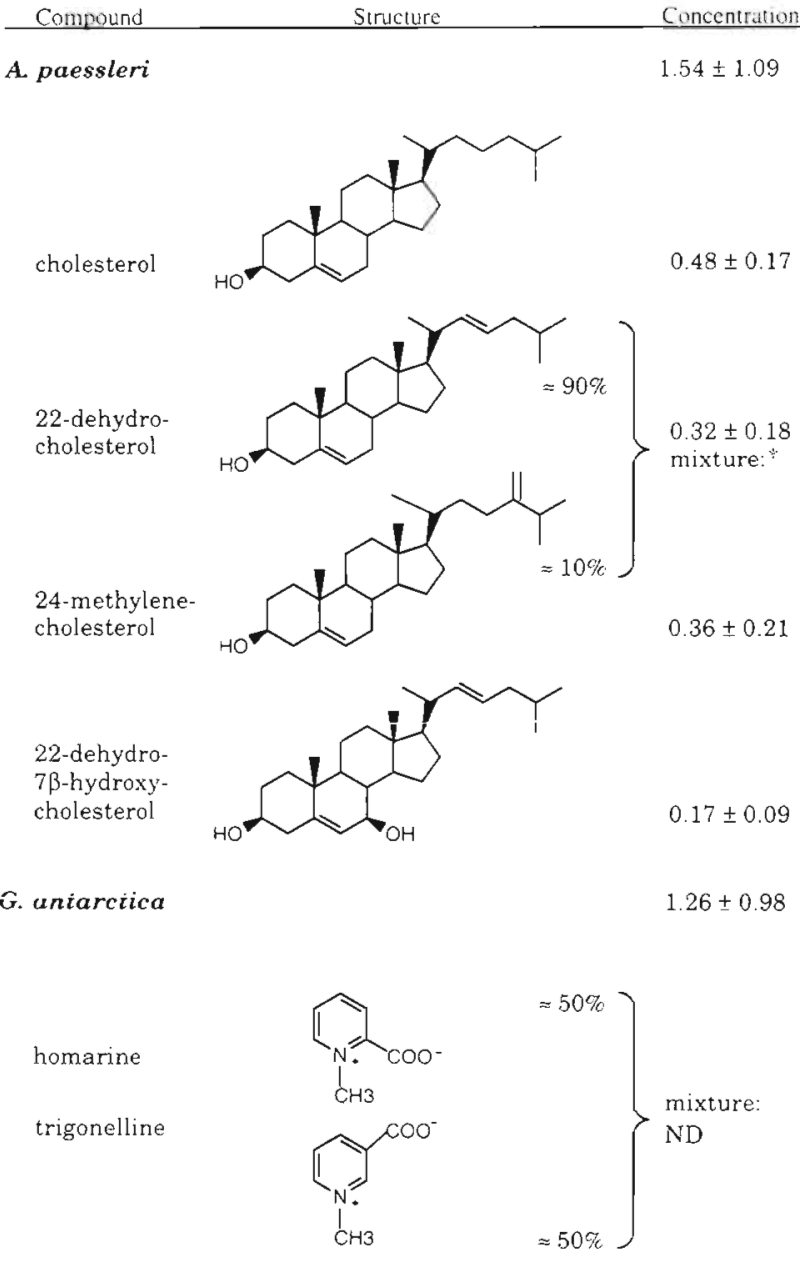

Fig. 2. Alcyonium paesslen and Gersemia antarctica. Concentration of water-borne organic fractions and metabolites released by the 2 soft corals reported as $\mathrm{mg} \mathrm{l}^{-1}$ of seawater extracted. Note: the mixture of 22-dehydrocholesterol and 24 methylenechlorestorol (*) was assayed at a 9:1 concentration in Antarctica; the absolute concentrations, as determined by analytical HPLC, are also reported here. The metabolite concentrations for $G$ antarctica were not determined (ND) as analytical standards were unavailable during our tenure in Antarctica

1:1 mixture (as determined qualitatively by NMR proton signal integration), as well as several minor metabolites (sterols and amino acids), but the concentration of these compounds could not be determined. In situ the metabolites released by $A$. paessleri diluted to extinction within a distance of $2 \mathrm{~cm}$ from the soft coral surface (Fig. 3). The metabolite 22-dehydro-7 $\beta$-hydroxycholesterol exhibited the greatest dilution and was not detectable beyond $1 \mathrm{~cm}$ from the soft coral surface. The rate of metabolite production for 3 size classes of $A$. paessleri (soft coral volume $=10,30$, and $60 \mathrm{ml}$ ) over $24 \mathrm{~h}$ was significantly different and positively correlated to colony size $(p=0.0156$; ANOVA: $F=4.370$, Scheffe's: $p=$ 


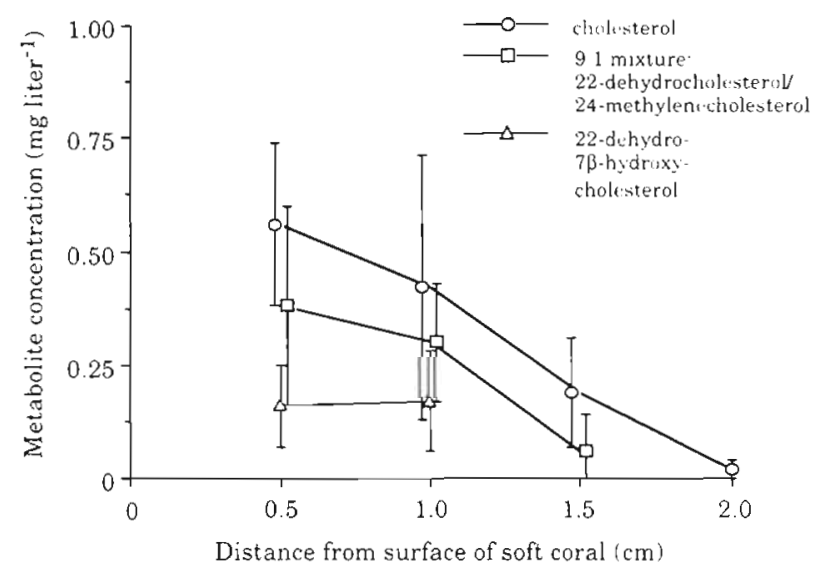

Fig. 3. Alcyonum paesslen. Dilution of metabolites released by the soft coral into the surrounding seawater. Following a preliminary study in which we realized the compounds diluted to extinction between 1 and $7 \mathrm{~cm}$, we adjusted the syringe arrays to sample at distances of $0.5,1.0,1.5$, and $2.0 \mathrm{~cm}$. Four samples were collected from an individual soft coral approximately $90^{\circ}$ apart and pooled to yield sufficient material (= $240 \mathrm{ml}$ ) for analyses. Data represent the mean concentrations reported as $\mathrm{mg}$ of sample $\mathrm{l}^{-1}$ seawater extracted at each distance $( \pm 1 S D, n=5$ replicate soft corals sampled)

0.0158 for the largest versus smallest size classes but $\geq 0.20$ for the mid size class compared to both extremes) (Table 1). The absolute rate of metabolite production, standardized to $1 \mathrm{ml}$ tissue volume, was also significantly different between size classes but only for 2 of the metabolites (cholesterol and 24methylenecholesterol; $\mathrm{p}=0.0169$ and 0.0139 , respectively); these data were negatively correlated to colony size (Table 1).

Table 1. Alcyonium paesslen. Daily production rates of water-borne metabolites by 3 size classes of the soft coral in the laboratory. No temporal trends were apparent in the quarterly samples collected over $24 \mathrm{~h}_{\text {; }}$ thus, the data represent the mean pooled metabolite concentrations as $\mathrm{mg} \mathrm{l}^{-1} \mathrm{~d}^{-1}$ of seawater extracted ( $\pm 1 \mathrm{SD}, \mathrm{n}=3$ replicates per size class). The absolute rate of production for each of the metabolites, standardized per $\mathrm{ml}$ of soft coral volume (i.e. $\mathrm{mg} \mathrm{l^{-1 }} \mathrm{d}^{-1} \mathrm{ml}^{-1}$ tissue volume), is reported in parentheses below each daily production value. $A$. paessleri exhibits amorphous growth patterns (Slattery \& McClintock 1995); thus, the soft corals were grouped into size classes based on volumetric displacement

\begin{tabular}{|lccc|}
\hline Metabolite & \multicolumn{3}{c|}{ Soft coral size (ml) } \\
\hline Cholesterol & 10 & 20 & 30 \\
& $1.44 \pm 0.52$ & $1.92 \pm 0.38$ & $2.64 \pm 0.34$ \\
$9: 1$ mixture & $(0.14 \pm 0.05)$ & $(0.06 \pm 0.01)$ & $(0.04 \pm 0.01)$ \\
22 -dehydrocholesterol/ & $0.72 \pm 0.20$ & $1.30 \pm 0.21$ & $1.53 \pm 0.59$ \\
24 -methylenecholesterol & $(0.09 \pm 0.02)$ & $(0.04 \pm 0.01)$ & $(0.03 \pm 0.01)$ \\
24-methylenecholesterol & $0.81 \pm 0.26$ & $1.11 \pm 0.20$ & $1.70 \pm 0.41$ \\
& $(0.08 \pm 0.03)$ & $(0.04 \pm 0.01)$ & $(0.03 \pm 0.01)$ \\
22-dehydro-7 $\beta$-hydroxy- & $0.58 \pm 0.37$ & $0.71 \pm 0.08$ & $0.73 \pm 0.19$ \\
cholesterol & $(0.06 \pm 0.04)$ & $(0.02 \pm 0.01)$ & $(0.01 \pm 0.00)$ \\
& & & \\
\hline
\end{tabular}

\section{Allelochemical bioassays}

The seastar Odontaster validus exhibited significantly longer tube-feet retraction periods ( $\mathrm{p} \leq 0.0001$; ANOVA: $F=538.393$, Scheffe's: $p \leq 0.0001$ for each) when exposed to the water-borne metabolites of Alcyonium paessleri including cholesterol, a 9:1 mixture of 22dehydrocholesterol/24-methylenecholesterol, and 22dehydro-7 $\beta$-hydroxycholesterol compared to the solvent control (Fig. 4) There was little or no difference in the bioactivity of these 3 compounds and they elicited a behavioral response similar to that of $0.1 \mathrm{M} \mathrm{CuSO}_{4}$. which is highly toxic to marine invertebrates (Sousa 1979). There was no difference in tube-feet retraction periods of seastars exposed to 24-methylenecholesterol compared to the control (Scheffe's: $p=0.0725$ ) The lack of a tube-feet response to either mechanical agitation of pure seawater or the facilatory feeding cues of pureed Antarctic cod indicate that the negative response of the seastars in experimental treatments were directly related to the chemical characteristics of those samples. Flight behavior of the seastars exposed to the water-borne soft coral metabolites (cholesterol, 9:1 mixture of 22-dehydrocholesterol/ 24 -methylenecholesterol, 22-dehydro-7 $\beta$-hydroxycholesterol, 24-methylenecholesterol; flight response in $53.3,40,66.7$, and $0 \%$ of the trials, respectively), while significant compared to the carrier, mechanical, and positive controls (flight response in $6.7,0$, and $6.7 \%$ of the trials, respectively), was not as predictable an indicator of deterrence as tube-feet retraction. For instance, the $\mathrm{CuSO}_{4}$ control elicited a flight response in $73.3 \%$ of the trials compared to tube-feet retraction in $100 \%$ of the trials.

Three Antarctic echinoderms exhibited a strong chemo-avoidance of water-borne cholesterol at field-relevant concentrations in a $y$-maze system $\left(\chi^{2}, \mathrm{p} \leq 0.05\right.$; Table 2). Cholesterol elicited no significant response from either the opisthobranch Tritoniella belli or the pycnogonid Collosendeis megalonyx $(\mathrm{p} \geq 0.05)$, but it did have a stimulatory effect on the nemertean worm parborlassia corrugatus ( $p \leq$ $0.05)$.

The organic extract of seawater collected near Gersemia antarctica significantly depressed the growth rate of 3 Antarctic microbes, Alteromonas sp., Moraxella sp., and Psychrobacter sp. ( $\mathrm{p} \leq$ 0.0001; ANOVA: $F=219.642$, Scheffe's: $p \leq 0.0001$ for each species), when compared to the control bacterial cultures (Fig. 5) The inhibitory effects 


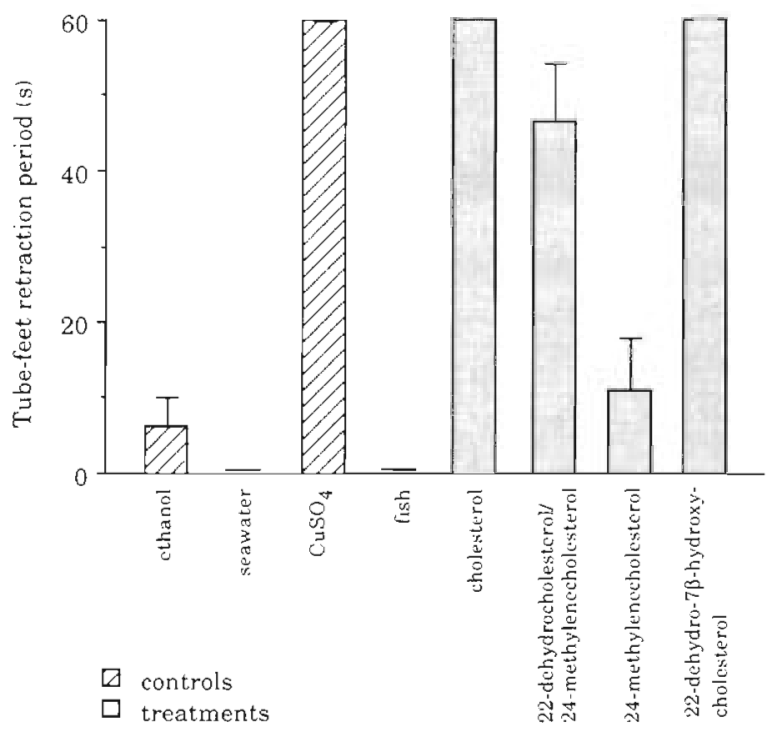

Fig. 4. Odontaster validus. Tube-feet retraction periods (= time between retraction and protraction of tube feet up to a maximum of $60 \mathrm{~s}$ ) of the common omnivorous seastar $O$. validus in response to pure and semi-pure metabolites isolated from the soft coral Alcyonium pássiter. Histuyrams represent the mean tube-feet retraction period in $s$ for each compound tested ( $\pm 1 \mathrm{SD}, \mathrm{n}=10$ replicates for each compound tested); thus, a smaller histogram represents a compound with little inhibitory effect on the seastar $O$. validus. Solvent, mechanical agitation, and positive and negative chemical cues were used as controls; statistical comparisons presented are

between the treatment and the solvent ( $\mathrm{EtOH}$ ) control

of the extract on bacterial population growth occurred within $24 \mathrm{~h}$ of exposure and the experimental bacterial populations never recovered. Similar trends were noted when the bacteria were exposed to the broad spectrum antibiotic standard, streptomycin. However streptomycin was significantly more bioactive than the $G$. antarctica organic fraction $(p \leq 0.0001)$. The pure standard of homarine, but not trigonelline (each tested at $0.16 \mathrm{mg} \mathrm{l}^{-1}$ ), exhibited antibacterial properties as in the original bioautography assays of the water-borne fraction; however, the zones of inhibition for the pure metabolite $(=10 \pm 2 \mathrm{~mm}$ ) were $3 \mathrm{~mm}$ narrower than for the crude extract (tested at $1.26 \mathrm{mg} \mathrm{l}^{-1}$ ). A weak, but non-significant trend for bacterial growth rate depression in all 3 bacteria ( 5 to $15 \%$ lower than controls) was noted for the Alcyonium paessleri water-borne organic fraction and these results are not reported further.

\section{DISCUSSION}

Direct evidence for the exudation and ecological roles of marine allelochemicals is very rare; our data and observations clearly indicate that the Antarctic soft corals Alcyonium paessleri and Gersemia antarctica
Table 2. Y-maze movement patterns of 6 species of common motile benthic invertebrates from McMurdo Sound in response to a pure water-borne metabolite released by the soft coral Alcyonium paessleri. The metabolite was subsequently identified using nuclear magnetic resonance (NMR) and mass spectrometry (MS) as cholesterol; thus, metabolite-intensive y-maze assays were conducted using pure cholesterol. Cholesterol was dissolved in ethanol and introduced to 1 arm of the maze in a random assignment at a concentration high enough to account for a downstream difution of $0.5 \mathrm{mg} \mathrm{l}$ ' seawater; a stumulatory cue was released from both arms of the maze to induce movement of the test organisms. The data represent preference for an arm of the $y$-maze (= percent directionality, $n=10-20$ replicates for each experimental and solvent control). A preference greater than $50 \%$ indicates chemo-avoidance of the cholesteroli less than $50 \%$ indicates chemo-attraction. The solvent control trials never differed significantly from random choice (i.e. $50 \%$ directionality; $\chi^{2}$, $p \geq 0.05$ )

\begin{tabular}{|c|c|c|c|}
\hline Species & $n$ & $\begin{array}{l}\% \text { dires- } \\
\text { tionality }\end{array}$ & $\begin{array}{l}\text { Signifi- } \\
\text { cance }\end{array}$ \\
\hline \multicolumn{4}{|l|}{ Nemertinea } \\
\hline Parborlasia corrugatus & 20 & 35.0 & $p \leq 0.05$ \\
\hline \multicolumn{4}{|l|}{ Mollusca } \\
\hline Tritoniella belli & 15 & 53.3 & $p \geq 0.05$ \\
\hline \multicolumn{4}{|l|}{ Arthropoda } \\
\hline Collosendeis megalonyx & 10 & 50.0 & $p \geq 0.05$ \\
\hline \multicolumn{4}{|l|}{ Echinodermata } \\
\hline Odontaster validus & 20 & 95.0 & $p \leq 0.05$ \\
\hline Perknaster fuscus & 20 & 95.0 & $p \leq 0.05$ \\
\hline Sterechinus neumayeri & 20 & 100.0 & $p \leq 0.05$ \\
\hline
\end{tabular}

release metabolites into the surrounding seawater and that these compounds serve predator deterrent and antibacterial roles, respectively. Previous work provided compelling evidence for defensive metabolites sequestered within these soft corals' tissues (Slattery \& McClintock 1995, 1997, Slattery et al. 1995); however, those studies never identified the compounds or determined if they were located in surficial tissues at ecologically relevant concentrations. The present study has identified defensive metabolites from these soft corals, at ecologically relevant concentrations, and in the location that is most advantageous to the producing organism: as water-borne compounds that surround their tissues. Most predator deterrent compounds are ingested following a grazing event (Paul 1992 and references within); this invariably results in some degree of tissue damage and metabolic costs associated with repair. Likewise, most antifoulant compounds are bioactive following contact; this may be too late to prevent the loss of nutrition or to prevent dislodgement due to increased drag forces (Witman \& Suchanek 1984, Sand-Jensen \& Revsbech 1987). In contrast, a water-borne allelochemical provides the selective advantage of a chemical defense uncoupled from the consequences of predator contact. 

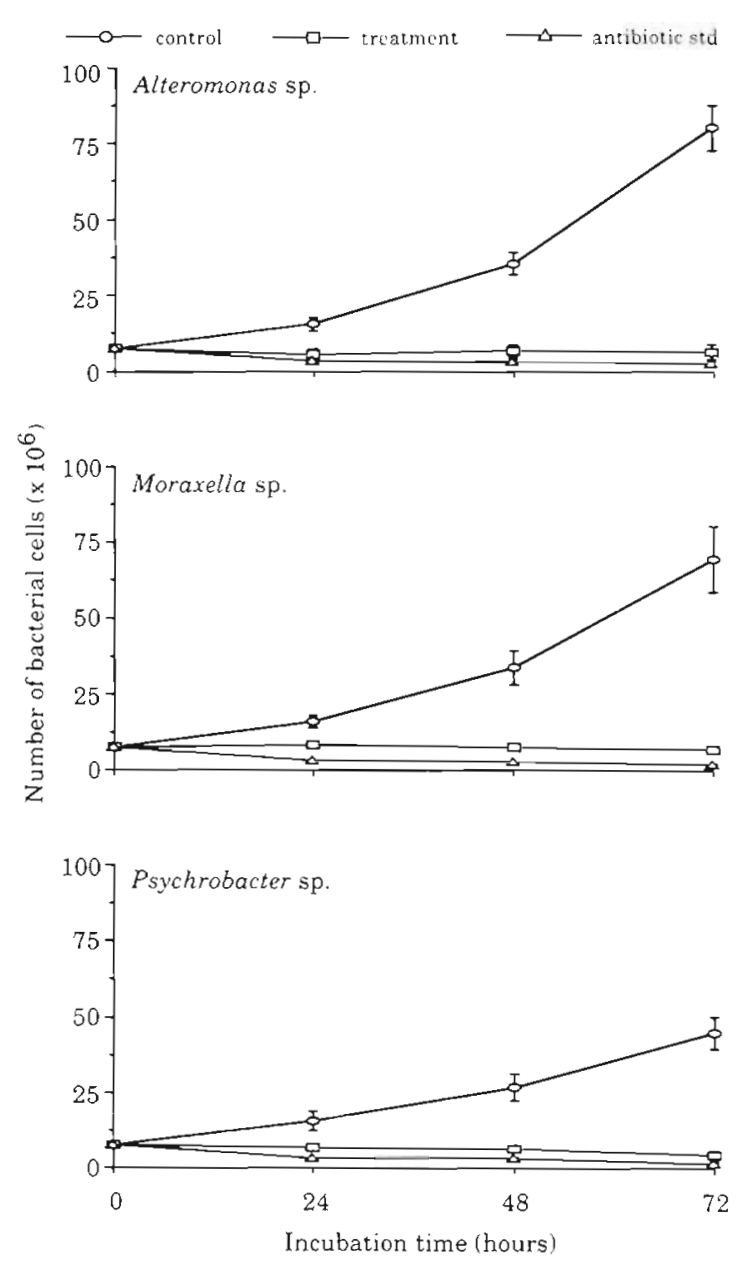

Fig. 5. Bacterial cell growth in the presence of an organic extract of seawater surrounding the soft coral Gersemia ant arctica. Cell growth over $96 \mathrm{~h}$ was measured indirectly by calibrated turbidity measurements. The extract was tested at water column concentrations (i.e. $1.26 \mathrm{mg} \mathrm{l}^{-1}$ seawater; see Fig. 2) and the antibiotic standard was tested at $10 \mu \mathrm{g} \mathrm{ml}$ ' Data points represent the corrected mean number of cells $\mathrm{ml}^{-1}( \pm 1 \mathrm{SD}, \mathrm{n}=5$ replicates $)$

Most studies that have addressed potential allelochemicals in the marine environment tend to emphasize their importance in competitive interactions between species and typically as a mechanism to control space (Jackson \& Buss 1975, Sammarco et al. 1983, Davis et al. 1991, de Nys et al. 1991, Maida et al. 1995). Competition is important in structuring Antarctic benthic communities below $30 \mathrm{~m}$ (Dayton et al. 1974). However, Alcyonium paessleri lives in moderately disturbed depths between 12 and $30 \mathrm{~m}$ (Slattery \& McClintock 1995, Slattery \& Bockus 1997) and appears to dominate by rapid growth and opportunistic recruitment (Slattery \& McClintock 1997). The western side of McMurdo Sound is characterized by sandy-mud substrate and little hard structure, thereby limiting the distribution of potential competitors of Gersemia antarctica; this soft coral has developed unique feeding and attachment mechanisms to capitalize on the local resources (Slattery et al. 1997). Thus, competition would not appear to be a selective mechanism for the development of water-borne allelochemicals by either of these species of soft corals. Instead the compounds appear to serve 2 different, but important, roles. In the case of $A$. paessleri, the intense potential predation pressure exerted by the myriad of local seastars (McClintock 1994b) and other benthic scavengers has apparently caused this species to select for waterborne predator deterrent compounds. Although this species is relatively common $\left(\bar{x}=7.3\right.$ soft corals $\mathrm{m}^{-2}$; Slattery \& McClintock 1995), we have never seen surface contact by either motile echinoderms or nemerteans (both very common benthic fauna; Dayton et al. 1974, Slattery pers. obs.). In fact we have made several in situ observations of seastars changing course to avoid contact with the surface of this soft coral $(n=$ 56 and 17 observations of Odontaster validus and Perknaster fuscus, respectively). Interestingly, seastars which have readjusted their course in the presence of A. paessleri appear to sense the soft coral at a distance of 1 to $2 \mathrm{~cm}$ (see Fig. 1), coincident with the dilution effects of the water-borne sterols we measured in situ. Soft coral predation events are thus limited to relatively rare attacks by specialists such as pycnogonids and opisthobranchs. Nonetheless, A. paessleri occasionally outcompetes the fast-growing sponge Mycale acerata (Slattery \& McClintock 1997); thus, a potential role for these allelochemicals in mediating interspecific competition cannot be discounted.

In contrast to the antipredation role of water-borne metabolites in Alcyonium paessleri, our results indicate that Gersemia antarctica possess water-borne antibacterial compounds. The ecological basis for production of antibacterial compounds has been the subject of much debate. Wahl (1989) argued that inhibition of bacterial settlement represents a mechanism to interrupt the specific successional sequences of surface fouling (a form of competition for space at the micro-scale). Others have suggested that bacterial pathogenesis and/or food capture may be the driving force for selection of antibacterial compounds (Berquist \& Bedford 1978). Slattery et al. (1995) provided evidence for compounds from G. antarctica which inhibited bacterial attachment and cell growth upon contact with the soft coral. The bioactive compounds were likely specific to either the attachment or growth processes as has been reported for temperate ascidian antimicrobials (Wahl et al. 1994). The present study indicates that sympatric bacteria are inhibited by $G$. antarctica metabolites prior to surface contact. Bacterial growth inhibition might occur in the surrounding 
seawater or at the sediment interface where the bacterial species were collected. Since this soft coral is a deposit feeder (Slattery et al. 1997), the production of antimicrobial agents to aid in food capture is an intriguing possibility that warrants further study

The bioactive allelochemicals produced by Alcyonium paessleri and Gersemia antarctica represent entirely different classes of compounds. This is not surprising given their taxonomic affinity and the diversity of compounds produced by octocorals (Sammarco \& Coll 1992). More surprising was the nature of the bioactive compounds within. A. paessleri. At least 3 sterols, i.e. cholesterol, 22-dehydro-7 $\beta$-hydroxycholesterol and 22-dehydrocholesterol, were active against the seastar Odontaster validus. The first 2 sterols and 24 -methylenecholesterol, which was not active, are common primary metabolites. Sterols are fairly ubiquitous throughout the eukaryotic lineage, where they serve a number of primary functions related to growth and reproduction. Recently a number of bioactive and medically important polyoxygenated sterols, including 22 -dehydro-7 7 -hydroxycholesterol, have been isolated from a diverse group of marine organisms (D'Auria et al. 1993 and references within); the mechanism of action for these compounds remains unclear but their cyctotoxicity might explain some of the bioactivity we recorded. Other sterols that have shown activity against predators include a cholesterol endoperoxide from the sponge Aplysilla glacialis (Bobzin \& Faulkner 1992) and 2 hydroxyecdysteroids from the sea spider Pycnogonum litorale (Tomaschko 1994). Perhaps most surprising was the antifoulant activity of a cholesterol 'control' reported by Davis et al. (1991). Our data clearly indicate that in situ, where multiple sterols accounted for approximately $86 \%$ of the water-borne metabolites released by $A$. paessleri, and in the laboratory, sterols have a deterrent effect on common Antarctic echinoderms. The same is not true of some echinoderms from tropic and temperate latitudes; cholesterol had chemoattractive qualities for the seastars Echinaster sp. (Florida Gulf Coast, USA) and Pisaster ochraceus (California, USA) (Slattery unpubl. data). The lack of chemoavoidance of cholesterol by the nudibranch Tritoniella belli and the pycnognid Collosendeis megalonyx likely reflects their trophic relationships to A. paessleri; the former is a cnidarian generalist while the latter is a specialist on A. paessleri. Although the nemertean worm exhibited chemo-attraction in our y-maze trials, none were ever observed actually contacting the soft coral in the field. It is possible that this scavenger has a positive chemosensory response to cholesterol released by decaying flesh, but is deterred by additional compounds released by $A$. paessleri. The site-specific variability of 22-dehydro-7 3 -hydroxycholesterol tissue concentrations is of interest since the highest levels were obtained from the soft corals of New I tarbor That site had significantly higher numbers of sea spiders (Thavmastopycnon sp.; Slattery \& McClintock 1997, Slattery et al. 1997); thus, the compound might be important in deterrence of these soft coral specialists as well as the generalist sea stars.

Gersemia antarctica released a diverse array of metabolites into the surrounding water column; at least 6 distinct TLC fractions of varying polarity were noted. Our research focused on an antibacterial fraction which contained a 1:1 mixture of homarine and trigonelline, as well as a very minor metabolite $(\leq 1 \mu \mathrm{g})$ which has not been identified to date. Homarine and trigonelline are fairly ubiquitous metabolites in marine invertebrates worldwide and probably serve a physiological role as osmolytes (Gasteiger et al. 1955, Baker \& Murphy 1976). Homarine is found in the Antarctic lamellarian Marseniopsis mollis at concentrations high enough to act as a colligative freezing point depressant (M. Slattery \& C. Avila unpubl.), however, it also deters feeding by the sea star Odontaster validus (McClintock et al. $1994 \mathrm{~b}$ ). Homarine is the antifoulant comnound in the sea whips Leptogorgia virgulata and $L$. setacea responsible for growth inhibition of the pennate diatom Navicula salinicola (Targett et al. 1983). Slattery et al. (1995) noted antifoulant activity in a polar fraction of the soft coral G. antarctica; however, they discounted homarine as the likely metabolite since TLCs indicated the presence of a compound that co-eluted with homarine standards in a nonactive fraction. The fact that trigonelline, which has a polarity similar to homarine but is not bioactive, has been found in our new samples might explain the apparent contradiction between the current results and those of our prior study (Slattery et al. 1995). Alternatively, additional bioactive metabolites might still be found; the bioactivity of pure homarine alone was not enough to explain the previous bioautography results with the crude water-borne fraction (i.e. the zones of inhibition varied).

In summary, the Antarctic soft corals Alcyonium paessleri and Gersemia antarctica produce bioactive sterols and homarine, respectively; that are released into the surrounding water column as predator deterrent compounds and antibacterial metabolites. The production of multiple metabolites that are potentially mimetic based on their similar structural characteristics could increase the concentration and, therefore, the signal of the bioactive constituent. There are costs associated with the constant production of allelochemicals that must be offset by the benefits of defense (Inderjit et al. 1995). We found that water-borne metabolite production is relatively constant over time; samples exhibited little variability with maximal metabolite concentrations produced within a $6 \mathrm{~h}$ period Allelochemicals would be most effective in low water 
velocity environments, where dilution is reduced. Currents in McMurdo Sound are generally low (Barry \& Dayton 1988); thus, dilution of these Antarctic soft coral allelochemicals would be minimal. Given these factors, it would appear that this system is ideal for the production and maintenance of these soft coral metabolites as water-borne allelochemicals.

Acknowledgements We are grateful to D. Bockus, P. Bryan, J. Heine, and J. Mastro for assistance with collections. J. Zwajiony synthesized the pure standards of homarine and trigonelline; for his efforts we are extremely grateful. J. Pawlik, J. Pearse, T Hopkins, K. Marion, S. Watts, and 2 anonymous reviewers provided useful comments on this manuscript. We also thank the Antarctic Support Associates, the National Science Foundation, and the US Naval Antarctic Support Force personnel at McMurdo Station for logistical support. This research was supported by N.S.F. grants to M.S (OCE-9528570), J.B.M. (OPP-9118864), and B. Baker (OPP9117216).

\section{LITERATURE CITED}

Bak RPM, Borsboom JLA (1984) Allelopathic interaction between a reef coelenterate and benthic algae. Oecologia 63: 194-198

Baker JT, Murphy V (1976) Handbook of marine science compounds from marine organisms, Vol 1. CRC Press, Cleveland, $\mathrm{OH}$

Barry JP, Dayton PK (1988) Current patterns in McMurdo Sound. Antarctica and their relationship to local biotic communities. Polar Biol 8:367-376

Berquist PR. Bedford JJ (1978) The incidence of antimicrobial activity in the Demospongiae: systematic and geographical considerations. Mar Biol 46:215-221

Bobzin SC, Faulkner DJ (1992) Chemistry and chemical ecology of the Bahamian sponge Aplysilla glacialis. J Chem Ecol 18:309-332

Bryan PJ, McClintock JB, Hamann M (1997) Behavioral and chemical defenses of marine prosobranch gastropod Calliostoma canaliculatum in response to sympatric seastars. J Chem Ecol 23:645-6.58

Castilla JC, Crisp DJ (1970) Responses of Asterias rubens to olfactory stimuli. J Mar Biol Assoc UK 50:829-847

Coll JC, Bowden BF, Tapiolas DM (1982) In situ isolation of allelochemicals released from soft corals (Coelenterata: Octocorallia): a totally submersible sampling apparatus J Exp Mar Biol Ecol 60:293-299

D'Auria MV. Minale L, Riccio R (1993) Polyoxygenated steroids of marine origin. Chem Rev 93:1839-1895

Davis AR, Butler AJ, van Altena I (1991) Settlement behavior of ascidian larvae: preliminary evidence for inhibition by sponge allelochemicals. Mar Ecol Prog Ser 72:117-123

Dayton PK, Robilliard GA, Paine RT, Dayton LB (1974) Biological accommodation in the benthic community at $\mathrm{MC}-$ Murdo Sound, Antarctica. Ecol Monogr 44:105-128

de Nys R, Coll JC, Price IR (1991) Chemically mediated interactions between the red alga Plocamium hamatum (Rhodophyta) and the octocoral Sinularia cruciata (Alcyonacea). Mar Biol 108:315-320

Gasteiger EL, Gergen J, Haake P (1955) A study of the distribution of homarine ( $\mathrm{N}$-methyl picolinic acid). Biol Bull (Woods Hole) 109:345-346
Hay ME (1996) Marine chemical ecology: what's known and what's next? J Exp Mar Biol Ecol 200:103-134

Fischer HB, Lust EJ, Koh RCY, Imberger J, Brooks NH (1979) Mixing in inland and coastal waters. Academic Press, New York

Inderjit KM, Dakshini $M$, Einhellig FA (1995) Allelopathy: organisms, processes, and applications. ACS Press, Washington, $\mathrm{DC}$

Jackson JBC, Buss L (1975) Allelopathy and spatial competition among coral reef invertebrates. Proc Natl Acad Sci USA 72:5160-5163

Lindquist N, Hay ME, Fenical W (1992) Defenses of ascidians and their conspicuous larvae: adult versus larval defenses. Ecol Monogr 62:547-568

Maida M, Sammarco PW, Coll JC (1995) Effects of soft corals on scleractinian coral recruitment. I: Directional allelopathy and inhibition of settlement. Mar Ecol Prog Ser 121 191-202

McClintock JB (1994a) An overview of the chemical ecology of antarctic invertebrates: The Ireland Lecture 1993. The University of Alabama at Birmingham

McClintock JB (1994b) Trophic biology of Antarctic shallowwater echinoderms. Mar Ecol Prog Ser 111:191-202

McClintock JB, Baker BJ, Hamann MT, Yoshida Y, Slattery M, Heine JN, Bryan PJ, Jayatilake GS, Moon BH (1994b) Hoamine as a feeding deterrent in common shallow-water Lamellarian Gastropod Marseniopsis mollis: a rare example of chemical defense in a marine prosobranch. J Chem Ecol 20:2539-2549

McClintock JB, Baker BJ, Slattery M, Hamann M, Kopitzke R, Heine J (1994a) Chemotactic tube-foot responses of the spongivorous sea star Perknaster fuscus to organic extracts from Antarctic sponges. J Chem Ecol 20:859-870

McGhee TJ (1991) Water supply and sewage. McGraw Hill, New York

Paul VJ (1992) Ecological roles of marine natural products. Cornell University Press, Ithaca, NY

Pawlik JR (1993) Marine invertebrate chemical defenses. Chem Rev 93:1911-1922

Pearse JS, McClintock JB, Bosch I (1991) Reproduction of Antarctic benthic invertebrates: tempos, modes, and timing. Am Zool 31:65-80

Porter JW, Targett NM (1988) Allelochemical interactions between sponges and corals. Biol Bull (Woods Hole) 175 $230-239$

Rice El. (1984) Allelopathy. Academic Press, Orlando, FL

Sammarco PW, Coll JC (1992) Chemical adaptations in the Octocorallia: evolutionary considerations. Mar Ecol Prog Ser 88:93-104

Sammarco PW, Coll JC, La Barre S, Willıs B (1983) Competitive strategies of soft corals (Coelenterata: Octocrallia): allelopathic effects on selected scleractinian corals. Coral Reefs 1:173-178

Sand-Jensen K, Revsbech NP (1987) Photosynthesis and light adaptation in epiphyte-macrophyte associations measured by oxygen microelectrodes. Limnol Oceanogr 32: $452-457$

Schmitt TM, Hay ME, Lindquist N (1995) Constraints on chemically mediated coevolution: multiple functions of seaweed secondary metabolites. Ecology 76:107-123

Slattery M. Avila C, Starmer J, Paul VJ (in press) A sequestered soft coral diterpene in the aeolid nudibranch Phyllodesmium guamensis. J Exp Mar Biol Ecol

Slattery M, Bockus D (1997) Sedimentation in Mc lurdo Sound. Antarctica: a disturbance mechanism for benthic invertebrates. Polar Biol 18:172-179

Slattery M, Heine JN, McClintock JB (1995) Chemical defenses 
in Antarctic soft corals: evidence for antifouling compounds. J Exp Mar Biol Ecol 190:61-77

Slattery M, McClintock JB (1995) Population structure and feeding deterrence in three shallow-water Antarctic soft corals Mar Biol 122:461-470

Slattery M, McClintock JB (1997) An overview of population biology and chemical ecology of three species of Antarctic soft corals. Proceedings of the 6 th lnternational SCAR Symposia. Cambridge University Press, Cambridge, p 309-315

Slattery M, McClintock JB, Bowser SS (1997) Deposit feeding: a novel mode of nutrition in the Antarctic colonial soft coral Gersemia antarctica. Mar Ecol Prog Ser 149:299-304

Sloan NA (1980) Aspects of the feeding biology of asteroids. Oceanogr Mar Biol Annu Rev 18:57-124

Sousa WP (1979) Experimental investigations of disturbance and ecological succession in a rocky intertidal algal community. Ecol Monogr 49:227-254

Targett NM, Bishop SS, MCConnell OJ, Yoder JA (1983) Antifouling agents against the benthic marine diatom Navicula salinicola: homarine from the gorgonians Leptogorgia virgulata and $L$. setacea and analogs. J Chem Ecol 9: $817-828$

Editorial responsibility: Joseph Pawlik (Contributing Editor), Wilmington. North Carolina, USA
Tomaschko KH (1994) Ecdysteroids from Pycnogonum litorale (Arthropoda, Pantopoda.) act as chemical delense aqainst Carcinus maenas (Crustacea, Decopoda). J Chem Ecol 20: $1445-1455$

Tyndale E, Avila C. Kuzirian AM (1994) Food detection and preferences of the nudibranch mollusc Hermissenda crassicornis: experiments in a Y-maze. Biol Bull (Woods Hole) $187: 274-275$

Wahl M (1989) Marme epibiosis. I. Fouling and antifoulıng: some basic aspects. Mar Ecol Prog Ser 58:17j-189

Wahl M, Jensen PR, Fenical W (1994) Chemical control of bacterial epibiosis on ascidians. Mar Ecol Prog Ser 110: $45-57$

Walker RP, Thompson JE, Faulkner DJ (1985) Exudation of biologically-active metabolites in the sponge Aplysina fistularis Il. Chemical evidence. Mar Biol 88:27-32

Webb L, Coll JC (1983) Effects of alcyonarian coral terpenes on scleractinian coral photosynthesis and respiration. Toxicon 3:485-488

Whitaker RH. Feeny PP (1971) Allelochemics: chemical interactions betwern species. Science 171:757-770

Witman JD. Suchanek TH (1984) Mussels in flow: drarg and dislodgement by epizoans. Mar Ecol Prog Ser 16:259-268

Submitted: August 15, 1997; Accepted: October 20, 1997 Proofs received from author(s): December 24, 1997 